\title{
Novel exogenous Calcium treatment strategies effectively mitigate physiological disorders in late season peach cultivars
}

\author{
J. Vala, S. Del Río, D. Redondo and A. Díaz \\ Departamento de Nutrición Vegetal. Estación Experimental de Aula Dei (EEAD-CSIC), \\ Avda. Montañana 1005. 50059, Zaragoza, Spain.
}

\begin{abstract}
To maintain fruit firmness and mitigate physiological alterations in a late season peach cultivar (Prunus persica '58GC-76'), environmentally friendly strategies including especial foliar calcium treatments, were developed. The innovation of these treatments consists of using an aqueous solution of the active matter $\left(\mathrm{CaCl}_{2}\right)$ and a separate organic phase containing a concentrated adjuvant (tara gum) which confers to the final applied solution good characteristics of sticking and wettability, among others. This permits the spreading of calcium on the fruit surface and when environmental humidity increases, calcium solution can penetrate the fruit surface. This way of applying exogenous calcium, is only used in our laboratory so far. Conventional foliar applied calcium was not considered in this work because our previous results demonstrated their lack of effectiveness to mitigate physiological disorders in this commodity.

Treatments at semi-industrial scale were conducted during 2014 and 2015 growing seasons. The very same pattern of treatments was applied to 58GC-76 peach orchards located in several sites of the 'Bajo Aragón' zone (NE Spain). The 58GC-76 variety suffers an emerging physiological disorder so called "corky spot" that has some similarities with vitrescent dark spot, which is affecting other late season peaches from the Protected Designation of Origin 'Calanda' in the same geographical region.

The evolution of fruit nutrients ( $\mathrm{Ca}, \mathrm{Mg}$ and $\mathrm{K}$ ), both in skin and pulp, demonstrated the effectiveness of calcium treatments during the two seasons in terms of increasing calcium concentration in both tissues. Regarding the evaluation of corky spot, a significant decrease in the severity and percentage of fruits affected was recorded in those fruits treated with calcium compared to control fruits which remained untreated.
\end{abstract}

Keywords: Prunus persica, calcium, fruit firmness, vitrescent dark spot, corky spot, tara gum

\section{INTRODUCTION}

Calcium is one of the limiting factors affecting fruit quality, in fact, is a key element in relation to firmness. Moreover, a higher concentration of calcium in fruit tissues provides commodities with a greater self-life, decreasing the probability of occurrence of physiological disorders that cause heavy losses to the fruit sector. One of these 
disorders has recently become important in late season peaches cv. 58GC-76 located at several sites of the 'Bajo Aragón' zone (NE Spain). It has been named as "corky spot" or "corking" and it manifests mainly in pulp and slightly in skin. The majority of the symptoms are located at the calix end of fruit and has the appearance of dried spots, with brown color and rough and spongy texture. This alteration, as well as many others, can be mitigated by providing extra calcium to the fruit. However, to provide calcium to fruit during the growing season, exogenous sprays to the fruit surface is in practice the only way to supply this nutrient, as its transport thorough the aerial part of the plant is carried out almost exclusively by the sap flow driven by transpiration force through the xylem (Bergmann, 1992). This implies that calcium accumulates in organs with a high transpiration rate as leaves and young meristems while those organs, as fruits, that have to prevent water loose to maintain turgidity and also develop large sizes may lose their quality due to an impairment in nutrient equilibria. Therefore, it has been demonstrated that an effective solution to prevent these disorders consist on the direct applications of calcium on the fruit surface, increasing the concentration of this nutrient in tissues of fruits as apples and peaches (Val et al, 2008) and, consequently, decreasing the incidence of physiological disorders. The aim of this study was to prove the effectiveness at a semi-industrial scale of new calcium foliar treatment strategies including new formulations tested in the laboratory and in small scale experimental plots. Tests in peach farms from the 'Bajo Aragón' area accounting on this 58GC-76 cultivar were carried out in two consecutive years. It can be concluded that these calcium treatments are capable to deal with this new physiological disorder in late season peach cultivars.

\section{MATERIALS AND METHODS}

\section{Experimental design}

The experiment was carried out in two commercial orchards located in the MidEbro Valley (Caspe, Zaragoza, Spain) during the growing seasons of 2014 and 2015. Trials were performed on mature trees of late season peach (Prunus persica L. Batsch '58GC-76'). Trees were selected to be as uniform as possible in terms of size and cropping.

The effect of applying treatments containing $0.3 \% \mathrm{CaCl}_{2}$ (Panreac; Barcelona, Spain) and 0.5\% Tara Gum (TG) (Hércules; Wilmington, DE, USA) as an adjuvant was evaluated under semi-industrial scale field conditions using an atomizer driven by a tractor. Foliar treatments started at stone hardening phase, and repeated weekly. Table 1 shows the dates of the foliar treatments. Differences among dates of treatments are due to the agroclimatic weather conditions of each year. No leafdamage (phytotoxicity) symptoms were observed after treatments and fruits were bagged after the last application, following the general practice of the area. Conventional foliar applied calcium was not considered in this work because our previous results (data not showed) demonstrated lack of effectiveness to mitigate physiological disorders in this commodity. 
Table 1. Date of foliar treatment with $\mathrm{CaCl}_{2}+$ Tara Gum

\begin{tabular}{cc}
\hline $\mathbf{2 0 1 4}$ & $\mathbf{2 0 1 5}$ \\
\hline $09-06-2014$ & $10-07-2015$ \\
$16-06-2014$ & $17-07-2015$ \\
$23-06-2014$ & $24-07-2015$ \\
\hline
\end{tabular}

Treatments were applied in randomized blocks with five replications, considering the single tree as experimental unit and comparing the results with those obtained for unsprayed, control trees, which only received standard farm treatments.

\section{Fruit samples}

Fruits were randomly and manually harvest on September 04, 2014 and September 01, 2015 and were transferred immediately to the laboratory.

\section{Quality parameters}

To evaluate quality parameters (destructive and non-destructive) 20 fruits per experimental unit were harvested. Polar diameter of each fruit was measured using a digital calliper (Mitutoyo; Tokyo, Japan). The colour coordinates were determined using the CIELab colour space with the aid of a spectrophotometer (Konica Minolta mod. CMS 700; Tokyo, Japan). Firmness was measured with a destructive MagnessTaylor measurement using a digital penetrometer (Agrosta; Forges Les Eaux, France) with a tip diameter of $8 \mathrm{~mm}$ and expressing the results as $\mathrm{kg} \mathrm{cm}^{-2}$. Soluble solid content (SSC) expressed as ${ }^{\circ}$ Brix was determined by crushing the flesh and transferring the intact juice of the 10 samples to a digital refractometer (Atago mod. PR-101; Tokyo, Japan). Titratable acidity (TA) was measured using an automatic titrator (Mettler Toledo mod. G20 Compact Titrator; New York, NY, USA). 10 grams of juice of 10 fruits were brought to $60 \mathrm{~mL}$ of distilled $\mathrm{H}_{2} \mathrm{O}$ and titrated with $0.1 \mathrm{~mol} \mathrm{~L}^{-1} \mathrm{NaOH}$ solution up to $\mathrm{pH}$ 8.1, expressing the results as g malic acid per kg.

\section{Macronutrient analysis}

For mineral analysis of macronutrients ( $\mathrm{Ca}, \mathrm{Mg}$ and $\mathrm{K}$ ) in skin and pulp, 10 fruits per experimental unit were taken at three stages: before the first foliar application of the calcium treatment, ten days after the last application and at harvest.

Fruits were washed and rinsed with deionized water and the skin and pulp were detached for the analysis. Both tissues were cut finely and weighed to obtain $0.5 \mathrm{~g}$ of skin and $1.0 \mathrm{~g}$ of pulp. Samples were digested with $5 \mathrm{~mL}$ of $69 \%$ nitric acid (w/v) (Panreac) and $5 \mathrm{~mL}$ of $30 \%$ peroxide of hydrogen (w/v) (Panreac) until the total evaporation of dissolution by heating in a hotplate. Once cooled, the remaining residue was re-suspended with $10 \mathrm{~mL}$ of $37 \%$ hydrochloric acid (w/v) (Panreac) and $5 \mathrm{~mL}$ of 3\% lanthanum as $\mathrm{LaCl}_{3}$ (Fluka, Buchs Austria), used to avoid spectral interference of phospahtes in calcium determination. It was brought to a volume of $50 \mathrm{~mL}$ with deionized water, in a volumetric flask. Analysis of mineral nutrients was performed by absorption spectrophotometry air/acetylene (Ca and $\mathrm{Mg}$ ) and atomic emission (K) with an atomic absorption equipment (Thermo Scientific iCE3000 Series; Waltham, MA, USA). The results are expressed as $\mathrm{mg} 100 \mathrm{~g}^{-1}$ fresh weight (FW). 


\section{Quantification of physiological disorder}

At harvest, 20 fruits per experimental unit were collected and stored immediately at $0-1{ }^{\circ} \mathrm{C}$ for 30 days. After that, the so called corky spot physiological disorder was visually identified and quantified according a homemade scale of the damage severity.

\section{Statistical analysis}

All samples were analysed in triplicate per year and the results presented as mean values \pm standard deviation. Statistical analyses were performed using a one-way ANOVA test and the significance of the difference between means was determined by Duncan's multiple range test $(p<0.05)$. Statistical analysis was performed using the Statistical Package for the Social Science (SPSS) software version 22.0.

\section{RESULTS AND DISCUSSION}

Few differences were found between control samples and those treated, in terms quality parameters analyzed at harvest. Only a slight increase in fruit firmness in 2014 campaign, was statistically different $(p<0.05$; Table 2$)$. This might indicate positive effects of calcium foliar treatment in fruit firmness. However, in 2015, this effect was not observed.

Table 2. Quality parameters of peach cv. N58 in 2014 and 2015.

\begin{tabular}{|c|c|c|c|c|c|c|c|}
\hline & $\begin{array}{l}\text { Caliper } \\
\text { (mm) }\end{array}$ & $\begin{array}{l}\text { Firmness } \\
\left(\mathrm{kg} \mathrm{cm}^{-2}\right)\end{array}$ & $\begin{array}{c}\text { SSC } \\
\text { (oㅗrix) }\end{array}$ & L (D65) & a (D65) & b (D65) & $\begin{array}{c}\text { TA } \\
\text { (g malic } \\
\text { acid kg-1) }\end{array}$ \\
\hline \multicolumn{8}{|c|}{ Harvest date: 04/09/2014 } \\
\hline \multirow{2}{*}{$\begin{array}{l}\text { Control } \\
\mathrm{CaCl}_{2}+ \\
\mathrm{TG}\end{array}$} & 74.1 & 4.4 & 13.1 & 65.6 & 16.0 & 50.0 & 5.9 \\
\hline & 74.6 & $4.7^{*}$ & 13.1 & 66.2 & 15.2 & $52.0^{*}$ & 5.8 \\
\hline \multicolumn{8}{|c|}{ Harvest date: 01/09/2015 } \\
\hline \multirow{2}{*}{$\begin{array}{l}\text { Control } \\
\mathrm{CaCl}_{2+} \\
\mathrm{TG}\end{array}$} & 85.1 & 5.2 & 15.0 & 65.1 & 20.5 & 52.1 & 9.1 \\
\hline & 84.7 & 5.1 & $14.2^{*}$ & 65.4 & $18.9^{*}$ & $49.7^{*}$ & 8.9 \\
\hline
\end{tabular}

*significant difference $(p<0.05)$.

The results obtained from calcium analysis carried out in the different fruit tissues at different sampling dates throughout the growing cycle are shown in Figure 1. Calcium concentration in both pulp and skin tissues followed the same trend during 2014 and 2015. Both tissues had the same calcium content in treated and untreated

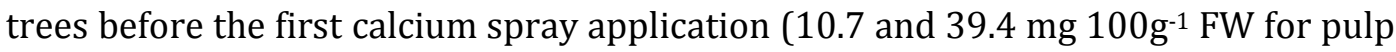

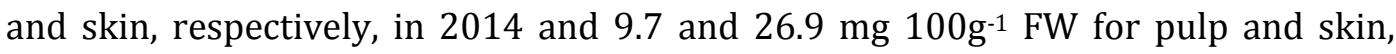
respectively, in 2015). The second mineral analysis, a week after the third treatment, showed a decrease in both tissues, and the content remaining similar in all cases. However, in last mineral analysis at harvest date, reveals that the concentration of calcium in both pulp and skin was remarkably lower in control samples (3.1 and 11.6 mg $100 \mathrm{~g}^{-1} \mathrm{FW}$ for pulp and skin, respectively, in 2014 and 3.4 and $9.2 \mathrm{mg}^{100 \mathrm{~g}^{-1} \mathrm{FW}}$ for pulp and skin, respectively, in 2015) than in the fruits treated with calcium (4.5

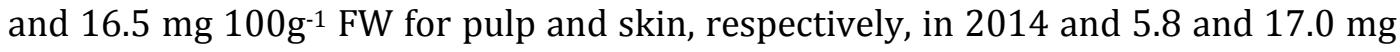
$100 \mathrm{~g}^{-1} \mathrm{FW}$ for pulp and skin, respectively, in 2015). 

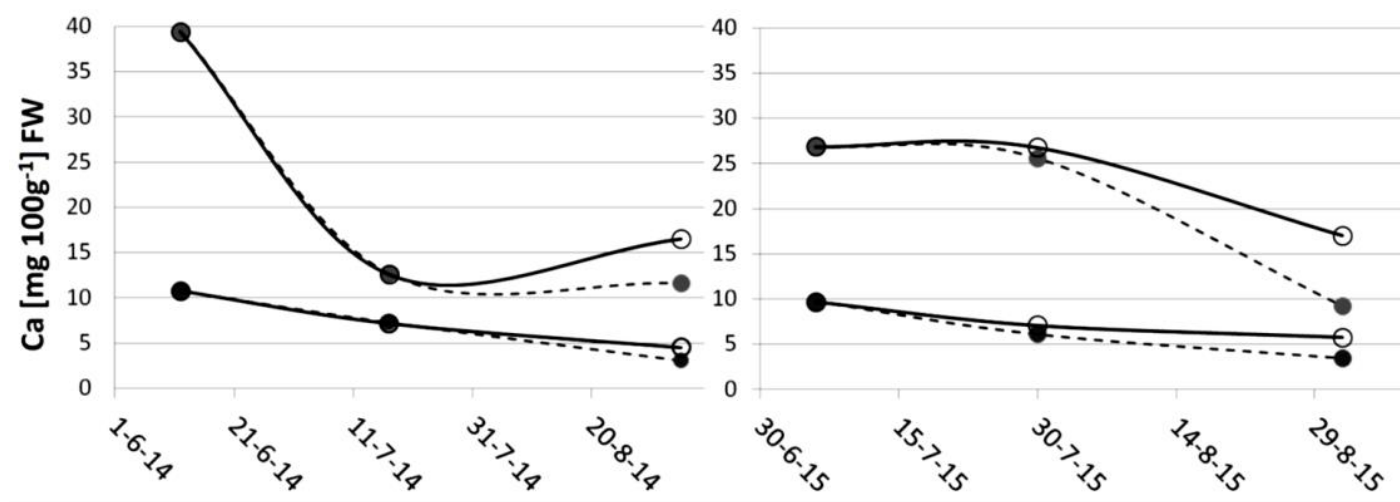

Significant differences $(\mathrm{p}<0.05)$ were found for all comparisons in the last sampling date.

Figure 1. Evolution of calcium in pulp and skin of 58GC-76 peaches in 2014 (left) and 2015 (right). Control (closed symbols) and $\mathrm{CaCl}_{2}+\mathrm{TG}$ (open).

Other nutrients related to fruit quality $(\mathrm{Mg}, \mathrm{K})$ showed a similar evolution of both elements in both campaigns and no statistically significant differences were observed between untreated fruits and those treated with Ca + TG. Magnesium content in 2014 decreased from 26.0 to $11.0 \mathrm{mg} 100 \mathrm{~g}^{-1} \mathrm{FW}$ in skin and from 17.0 to $7.0 \mathrm{mg}^{100 \mathrm{~g}^{-1} \mathrm{FW}}$

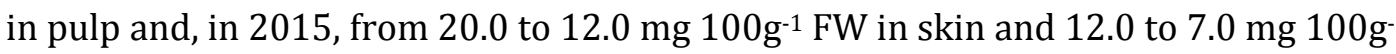
${ }^{1} \mathrm{FW}$ in pulp. For potassium content, although the behavior in the midpoint was different, the content also decreased with time.

The incidence of corky spot was studied after 30 days of cold storage at $0^{\circ} \mathrm{C}$. It was observed that in both campaigns the percentage of affected fruits was higher in the control group $3.1 \%$ in 2014 and $14.7 \%$ in 2015$)$ than in those who had been treated with Ca+ TG (1.1\% in 2014 and 8.0 in 2015) (Data not shown).

In order to characterize this new physiological disorder, Table 3 shows the results obtained from the mineral analysis of different tissues from corky spot affected fruits harvested on 2015. While calcium content was almost similar in healthy pulp and in the cork spot tissue $\left(3.5 \mathrm{mg} 100 \mathrm{~g}^{-1}\right)$, it was slightly lower $\left(2.5 \mathrm{mg}\right.$ Ca $100 \mathrm{~g}^{-1}$ ) in adjacent areas of the spot. Magnesium concentration was practically the same on healthy pulp and on the area adjacent to that damaged (around $7.0 \mathrm{mg} 100 \mathrm{~g}^{-1}$ ) but twice in the very spot $\left(16.0 \mathrm{mg} 100 \mathrm{~g}^{-1}\right.$ ). Finally, the lowest concentration of potassium was observed in healthy pulp (279.0 mg $100 \mathrm{~g}^{-1}$ ), increasing sharply in the adjacent area of the spot (412.2 mg $100 \mathrm{~g}^{-1}$ ) and the highest content was found in the corky spot

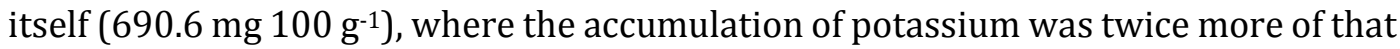
observed in the healthy pulp.

Peach fruits from the protected designation of origin 'Melocotón de Calanda' a late season group of cultivars, usually are affected by 'vitrescent dark spot' (VDS). Our group performed a set of preliminary trials in an attempt to mitigate the existing lack of information on this peach disorder (Fernandez et al., 2012). Analysis of mineral 
elements in the injured tissues has shown that $\mathrm{Ca}$, and $\mathrm{Mg}$ concentrations were greater than in the mesocarp of sound fruits, while in sound mesocarp of VDS affected fruits, the concentrations were smaller. For K, the opposite situation was found. Besides, analysis of pulp of affected fruits showed increasing concentrations of $\mathrm{Ca}$ and $\mathrm{Mg}$ from sound tissue towards the spot, being greatest close to the spot.

In this work, corky spot areas contain significantly higher concentrations of $\mathrm{Mg}$ than that found in sound tissues and also greater concentration of potassium (Table 3). This pattern does not match the one found in VDS in late season peaches, and also to the mineral composition of other calcium related alterations of other commodities as bitter pit of apples.

Table 3. Composition in $\mathrm{Ca}, \mathrm{Mg}$ and $\mathrm{K}$ in healthy and corky áreas of 58GC-76 peaches in 2015. Means with the same letter, in the same column are not significantly different from each other (Waller-Duncan test, $p>0.05$ )

\begin{tabular}{lccc}
\hline & Ca & Mg & K \\
\hline Adjacent to cork & $2,5 a$ & $7 a$ & $412,2 a$ \\
Corky spot & $3,5 b$ & $16 b$ & $690,6 b$ \\
Sound fruit & $3,6 b$ & $7,4 a$ & $278,0 a$
\end{tabular}

\section{CONCLUSIONS}

Foliar treatments with calcium + tara gum were effective since in both campaigns treated fruits at harvest contained greater calcium concentration than those untreated. This was found in two tissues, pulp and skin but negligible differences in fruit quality were observed.

Regarding to the mitigation of "corky spot", a lower incidence in both campaigns was observed for treated fruits, being this decrease more important in the second year of study. However, the appearance of this disorder is highly dependent on the year and agro climatic conditions. Moreover, the emerging study of the tissues affected by this disorder, reveals high concentrations of $\mathrm{Mg}$ and $\mathrm{K}$ and similar content of $\mathrm{Ca}$ in pulp compared to the healthy tissue. This alteration is becoming more important in the Bajo Aragón area, therefore the continuation of this research deserves further efforts in future campaigns.

\section{ACKNOWLEDGEMENTS}

This work has been funded by the project 'Mejora de la calidad del melocotón de Calanda: material vegetal, técnicas culturales, conservación y comercialización' and by the grant from de Spanish Ministry of Economy and Competitively 'Mejora Genética de patrones Prunus y variedades de melocotonero' (AGL2014-52063-R). 


\section{Literature Cited}

Bergmann, W. (1992). Nutritional disorders of plants: development, visual and analytical diagnosis. $3^{\text {th }}$ edn. (Jena, Germany: Gustav Fischer). pp.742.

Fernandez, V., Blanco, A., and Val, J. (2012). Vitrescent dark spot in peach: a preliminary mineral element characterization. Acta Horticulturae 962, 495-498.

Val, J., Espada, J.L., Monge, E. and Blanco, A. (2010). The Effects of Ca Applications on Peach Fruit Mineral Content and Quality. Acta Horticulturae 868, 405-408. 